\title{
Human-environment interactions in residential areas susceptible to landsliding: the Flemish Ardennes case study
}

\author{
Miet Van Den Eeckhaut*,**, Jean Poesen*, Liesbeth Vandekerckhove ${ }^{\dagger}$, \\ Marijn Van Gils*,t+, and Anton Van Rompaey*
}

*Physical and Regional Geography Research Group, K.U. Leuven, Celestijnenlaan 200E, B-3001 Leuven, Belgium

Email: miet.vandeneeckhaut@ees.kuleuven.be

**Research Foundation - Flanders, 1000 Brussels, Belgium

tEnvironment, Nature and Energy Department, Flemish Government, 1000 Brussels, Belgium

${ }^{+\dagger}$ Flemish Heritage Institute, 1210 Brussels, Belgium

${ }^{\ddagger}$ Prehistoric Archaeology Unit, K.U. Leuven, B-3001 Leuven, Belgium

Revised manuscript received 21 August 2009

\begin{abstract}
Studies on landslide susceptibility and landslide risk generally start from the assumption that mainly natural factors control the occurrence of landslides. The role of human activity is considered less important. We investigated the role of human-environment interactions in the Flemish Ardennes, Flanders' most landslide-susceptible region. The establishment of a detailed landslide inventory brought insight into the spatial occurrence of landslides and into the different landslide types and characteristics. A statistical model, i.e. logistic regression, allowed the significance of environmental factors controlling landslide occurrence to be determined, and a landslide susceptibility map to be produced. Being a residential area, however, the Flemish Ardennes is a region where humans play an active role with regard to landslide risk. Although the location of many archaeological sites in this area is known, almost no archaeological sites are found on landslide-susceptible hillslopes. This might indicate that in prehistorical and historical times humans were more familiar with local environmental characteristics and avoided unstable hillslopes. Comparison of topographic maps (17772001), on the contrary, indicate that over the last 250 years buildings and other infrastructures have been constructed on old landslides. Given that humans are living, working and driving on or close to unstable hillslopes, the landslide risk has therefore increased. The landslide inventory map and the landslide susceptibility map are important tools for landslide risk reduction. Here 'science meets policy', as both maps allow linking construction norms and other mitigation measures to hillslopes already affected by landslides and to susceptibility classes with very high, high and moderate landslide susceptibility.
\end{abstract}

Key words: landslide inventory, landslide susceptibility, natural and anthropogenic causal factors, landslide damage 


\section{Introduction}

The interaction between humans and the environment is a central theme in geography (Goudie 2000). In most landslide studies, attention is mainly paid to the influence of natural factors on the occurrence of landslides. Humans are mainly regarded as subjects that are vulnerable to landslides, and not as actors influencing slope stability (Panizza 1999). Recent studies focusing on the effect of human-induced land use changes on slope stability (for example, Claessens et al. 2006; Petley et al. 2007; Tarantino et al. 2007; Meusburger and Alewell 2008), however, have shown that in populated regions, the impact of humans on the environment has an important contribution to the initiation and reactivation of landslides.

Landslides, defined by Cruden (1991) as the movement of rock, debris or earth down a slope, are generally considered to be an important degradation process in mountainous areas. However, not all regions suffering damage caused by landslides are mountainous. In Europe, for example, landslides have also been reported in hilly areas around Bonn (Schmidt and Dikau 2004), in the Champagne-Ardennes (Marre 1987), in the London basin (Hutchinson 1967) and in two regions in Belgium. About ten deep-seated landslides have been reported in the Pays de Herve (East Belgium; Demoulin et al. 2003), but landslides are more numerous in the Flemish Ardennes, a hilly region located south of Ghent (Vanmaercke-Gottigny 1980; Ost et al. 2003; Van Den Eeckhaut et al. 2005a 2007a; Dewitte et al. 2008).

The objective of this study is to discuss humanenvironment interactions and their influence on landsliding in the Flemish Ardennes (Figure 1). With regard to the influence of the environment on landslides and the consequences for humans, this study addresses two research questions: which environmental characteris-

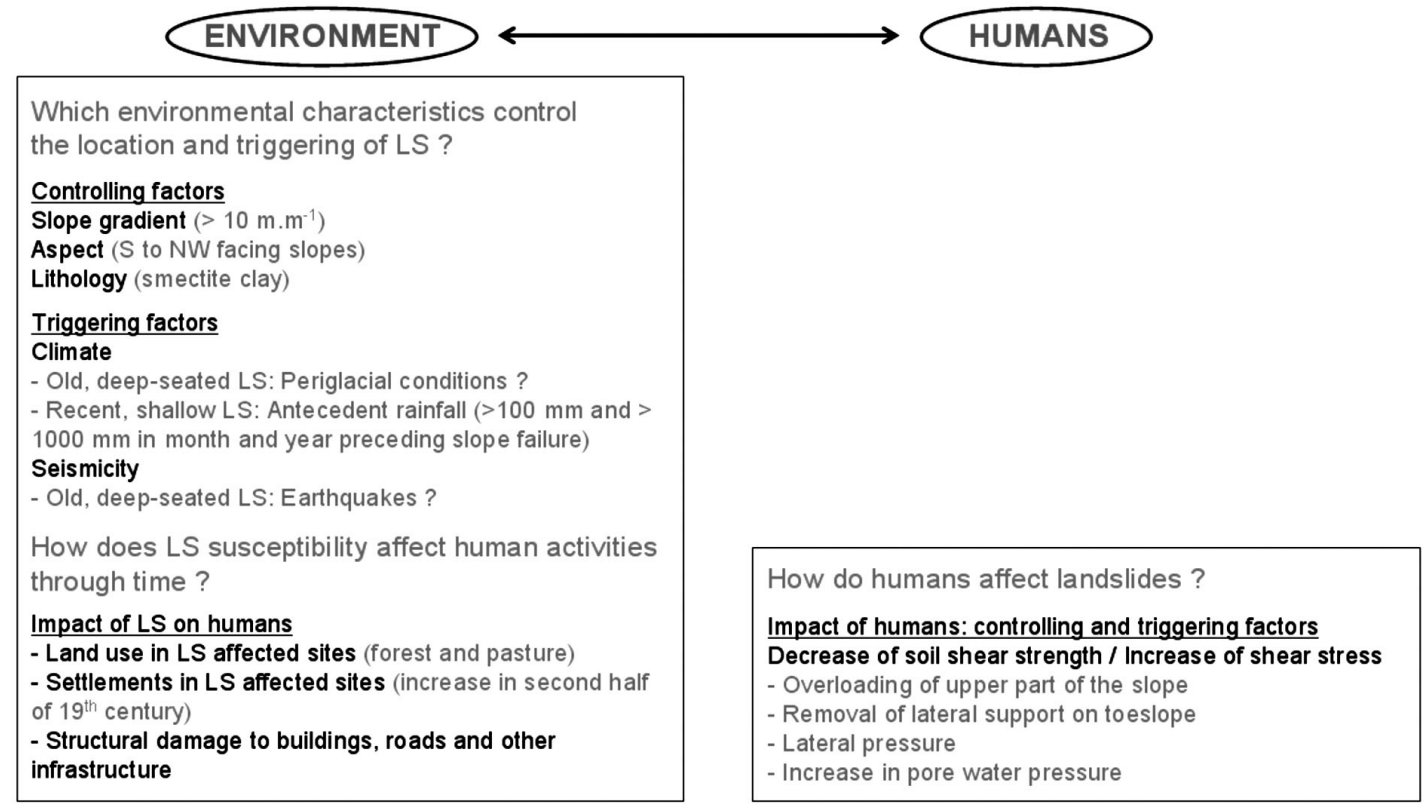

Figure 1 Human-environment interactions in residential areas susceptible to landsliding with focus on the Flemish Ardennes 
tics control the location and triggering of landslides, and how does landslide susceptibility affect human activities through time? With regard to the human impact on landslides the major question is: how do humans affect landslides? After focusing on humanenvironment interactions, we provide answers to what are the implications for land management. The sections answering these four research questions are preceded by a brief description of the Flemish Ardennes and the landslides in this study area.

\section{Study area and regional landslide inventory}

The Flemish Ardennes, a $710 \mathrm{~km}^{2}$ hilly region in the southeastern part of Flanders, Belgium (Figure 2) is characterised by elevations ranging from $20 \mathrm{~m}$ asl, in the valley of the River Scheldt, to $150 \mathrm{~m}$ asl, on the hilltops in the southern part of the area. About 5.3 per cent of the area has slopes steeper than $0.10 \mathrm{~m} \mathrm{~m}^{-1}$. Due to valley asymmetry, these steeper slopes are mainly facing the south and the northwest (Figure 2).

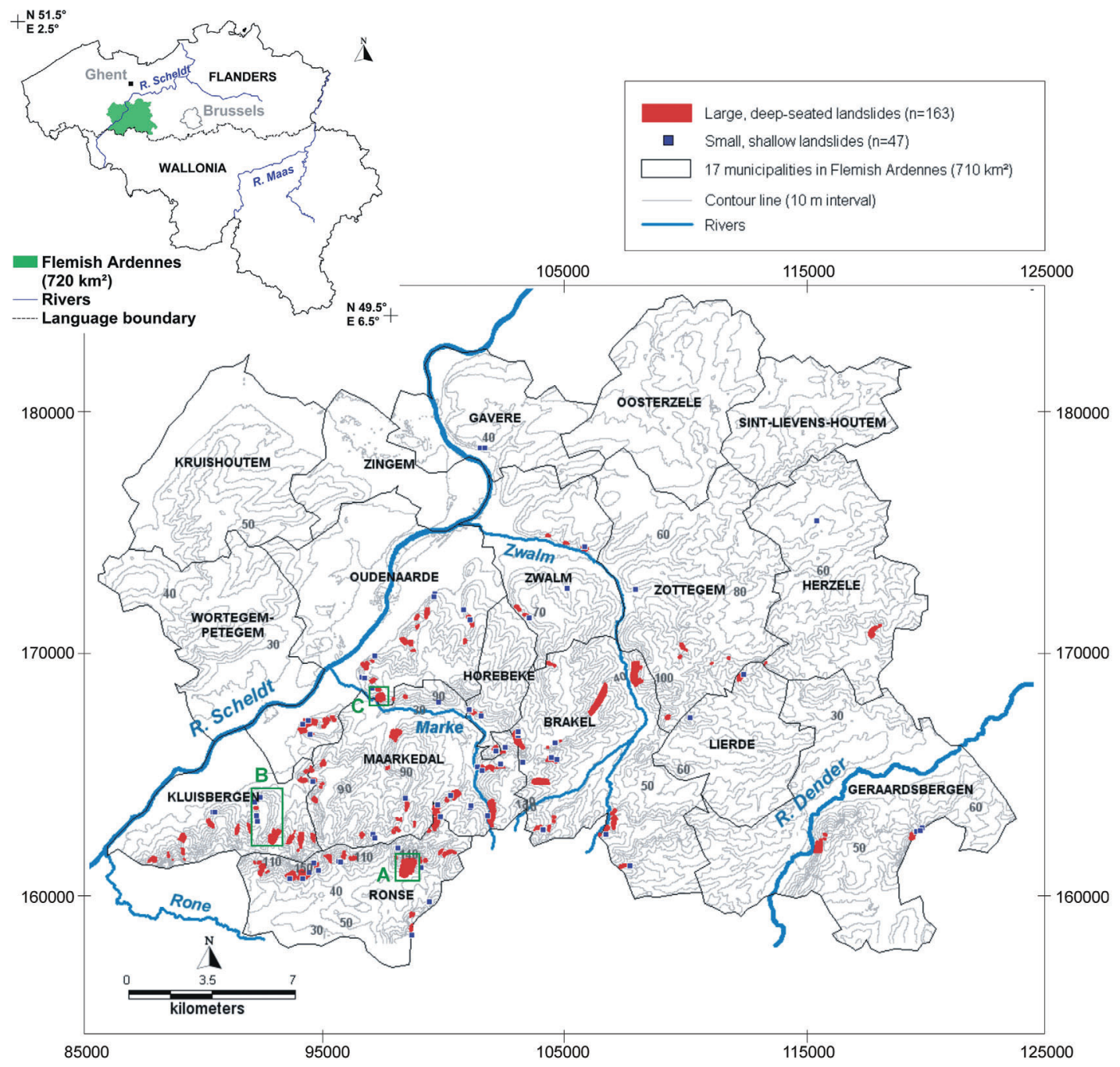

Figure 2 The study area in the Flemish Ardennes showing the 17 municipalities and the major rivers. An overlay with the landslide inventory shows a higher concentration of landslides south of the Scheldt. Rectangles indicate

Muziekberg landslide (A; Figure 3, 8), Paterberg (B; Figure 7) and Hekkebrugstraat landslide (C; Figure 11)

Area Vol. 42 No. 3, pp. 339-358, 2010

ISSN 0004-0894 (C) The Authors.

Journal compilation (c) Royal Geographical Society (with The Institute of British Geographers) 2009 
The study area is underlain by gently dipping marine sediments, Eocene and Miocene (Tertiary) in age. The oldest sediments crop out in river valleys and consist of silty clay and coarse clayey silt with intercalations of clay layers, pertaining to Saint Maur and Moen Members of the Kortrijk Formation (Jacobs et al. 1999a 1999b). The upper part of the Kortrijk Formation, i.e. the Aalbeke Member, consists of homogenous blue smectite clay. It is overlain by silty clay sand with glauconite of the Tielt Formation. Younger sediments, with a more limited spatial occurrence, crop out at the top of the hills. The Gent Formation, with the clayey Merelbeke Member and the sandy Vlierzele Member, is consequently overlain by the Lede Formation, made up of fine sand, by the Maldegem Formation, comprising homogeneous blue clay and glauconitic sandy clay, and by the Diest Formation, consisting of yellow brownish glauconitic sand.

In the late Tertiary and early Quaternary, differential erosion of lithological layers shaped the topography in the area (Figure 2). During cold periods in the Pleistocene, niveo-eolian sediments covered the preexisting Quaternary topography (IWONL 1987). From north to south, the percentage of sand decreases for silt. As a consequence, soils with different textures are present in the area (IWONL 1987). In the southern part of the study area, slopes and plateaus are covered by loess. Soils on loess-covered gentle slopes and plateaus are generally dry. Wet soils are present where Holocene alluvial and colluvial sediments crop out, and where Tertiary clay hampers infiltration locally (Closson et al. 1999). Perched water tables build up locally when permeable sands rest on less permeable clay.

Landslides were mapped through detailed field mapping, aided by the visual analysis of LIDARderived (Light Detection and Ranging) hillshade and contour line maps. After evaluating this mapping approach for a $125 \mathrm{~km}^{2}$ test area (Van Den Eeckhaut et al. 2007a), a regional landslide inventory map of the complete Flemish Ardennes $\left(710 \mathrm{~km}^{2}\right)$ was obtained at a 1:10 000 scale (Figure 2). Figure 3 shows an excerpt of the LIDAR-derived hillshade and contour line maps depicting the south-facing slope of the Muziekberg hill (see Figure 2 for location). Analysis of these maps allowed identification of the largest (42 ha) landslide of the Flemish Ardennes. Apart from typical morphological characteristics of landslides (for example, main scarp currently under forest, reverse slope and convex landslide foot) the maps indicate that the course of the river at the foot of the landslide has been displaced by landslide debris, and also some traces of reactivations are visible. The regional inventory (Figure 2) shows 210 landslides, equivalent to a density of one landslide every $3.4 \mathrm{~km}^{2}$. However, landslides are not equally distributed throughout the area. The inventory map shows a higher density of landslides in the hilly area south of the River Scheldt. Of the total number of observed landslides, 77.6 per cent $(n=163)$ are deepseated, i.e. the shear surface was estimated to be deeper than $3 \mathrm{~m}$, and larger than 1 ha (average 4 ha; for example, Figures 3 and 4A,B). The estimation of shear surface depth is based upon the deformation of the terrain and the height and shape of the main scarp. A depth of $3 \mathrm{~m}$ was chosen because this value was also used in other studies (for example, Keefer 1994). These deep-seated landslides are mainly classified as rotational earth slides (Cruden and Varnes 1996) in the inventory map. Shallow landslides represent 22.3 per cent $(n=47)$ of all landslides shown in the inventory, and individually occupy an area of less than 1 ha (average 0.5 ha; Figure 4C,D). They have an estimated depth of less than $3 \mathrm{~m}$, and are classified chiefly as rotational slides with a flow component at the toe (Cruden and Varnes 1996). Many of the shallow failures occurred inside pre-existing deep-seated landslides.

\section{Which environmental characteristics control the location and triggering of landslides?}

Environmental factors controlling spatial

landslide patterns are summarised in a

landslide susceptibility assessment

Understanding the role of individual factors controlling landslide location is important for predicting 'where' landslides can occur in the future, i.e. to ascertain 'landslide susceptibility' (Varnes and IAEG 1984). In the past three decades, a large number of qualitative and quantitative methods were applied and tested to ascertain landslide susceptibility, and to zone a territory based on its propensity to generate slope failures (Carrara et al. 1995; Soeters and van Westen 1996; Guzzetti et al. 1999; Dai et al. 2002; Glade and Crozier 2005).

For modelling landslide susceptibility in large areas, logistic regression is nowadays a common statistical modelling technique (for example, Carrara et al. 1995; Atkinson and Massari 1998; Begueria and Lorente 1999; Ayalew and Yamagishi 2005; Lee 2007). We adopted a specific type of logistic regression, i.e. Rare Events Logistic Regression (RELR; King and Zeng 2001), that accounts for the low spatial occurrence of 


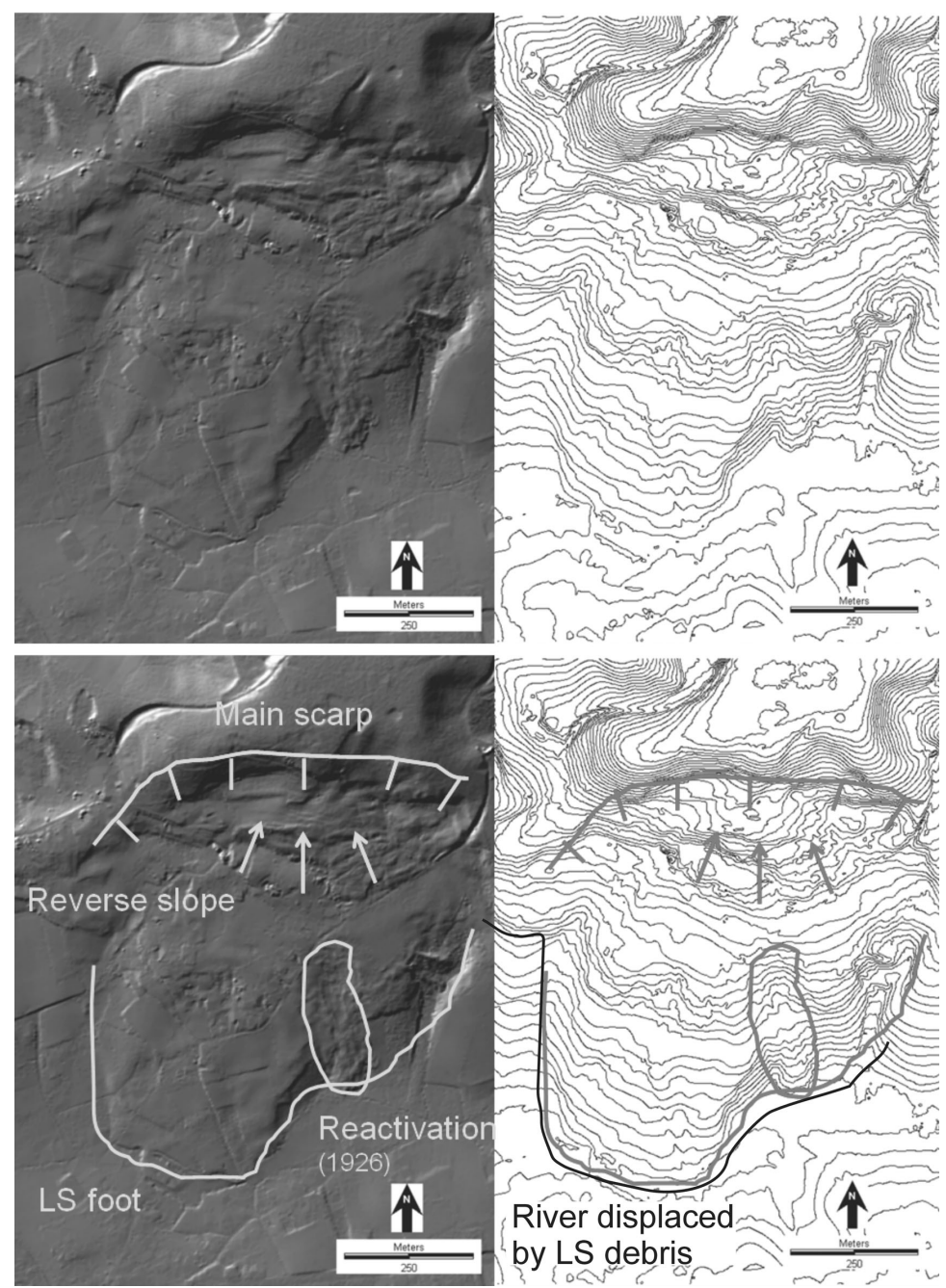

Figure 3 LIDAR-derived hillshade and contour line maps showing the Muziekberg landslide, the largest (42 ha) landslide of the Flemish Ardennes. Apart from typical morphological characteristics of landslides (e.g. main scarp, reverse slope and convex landslide foot), the maps indicate that the course of river downslope of the landslide foot has been displaced by landslide debris, and also traces of reactivations are visible. See Figure 2 for location of the Muziekberg landslide and Figure 8 for the excerpt of the topographical map of this landslide

landslides in the study area. The use of this statistical model for landslide susceptibility assessment was first evaluated for a $200 \mathrm{~km}^{2}$ test area (Van Den Eeckhaut et al. 2006) and recently applied to the complete Flemish Ardennes. For this, the study area was divided into grid cells with a $10 \mathrm{~m} \times 10 \mathrm{~m}$ resolution, and each grid cell was given a code of ' 1 ' or ' 0 ' indicating the 'presence' or 'absence' of a mapped landslide. Then RELR was applied to find the best-fitting model describing the relationship between the dependent variable (i.e. the presence or absence of depletion areas of large, deep-seated landslides) and a set of independent variables (i.e. terrain height, slope gradient, aspect, plan and profile curvature, Tertiary geology, soil drainage, distance to rivers and distance to faults). Categorical independent variables were dummy coded into multiple binary variables. If there are $m$ categories, the variable was replaced by $m-1$ dummy variables. Each category's dummy variable has a value of ' 1 ' when this category is present in the grid 

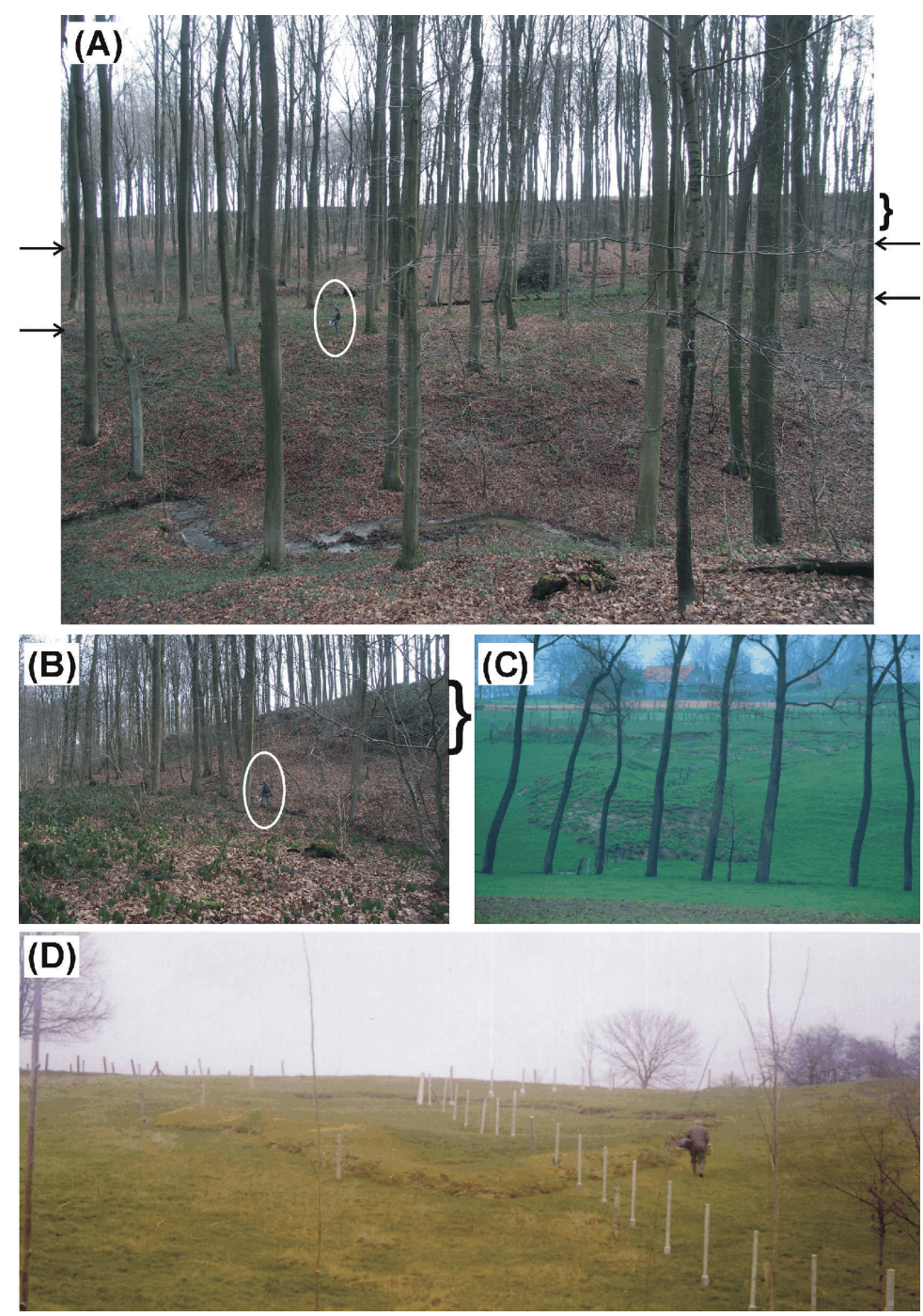

Figure 4 Illustration of some typical landslides in the study area. (A) Large, deep-seated landslide in Brakel forest (Brakel; 16/02/2007). Person indicates scale, black arrows indicate two reverse slopes, accolade indicates main scarp. (B) Depletion area of large, deep-seated landslide shown in (A). The person is standing in the deepest part of the reverse slope. Accolade indicates main scarp. (C) Shallow landslide in Schorisse initiated in January 1999 (Maarkedal). (D) After reshaping the slope shown in (C) by a bulldozer in September 2003 a shallow landslide occurred in January 2004

cell and a value of ' 0 ' when another category is present. One category, the reference category, doesn't need its own dummy variable, as it is uniquely identified by all the other variables being 0 . To avoid interdependency between the independent variables, multicollinearity was evaluated using the Variance Inflation Factor, Tolerance and Condition index
(Hosmer and Lemeshow 1989; Campling et al. 2002). This analysis learned that geology and terrain height, and plan and profile curvature were interdependent and could not be included in the same model.

Several models based on different combinations of independent variables were evaluated with the same evaluation parameters as explained in Van Den Eeck- 


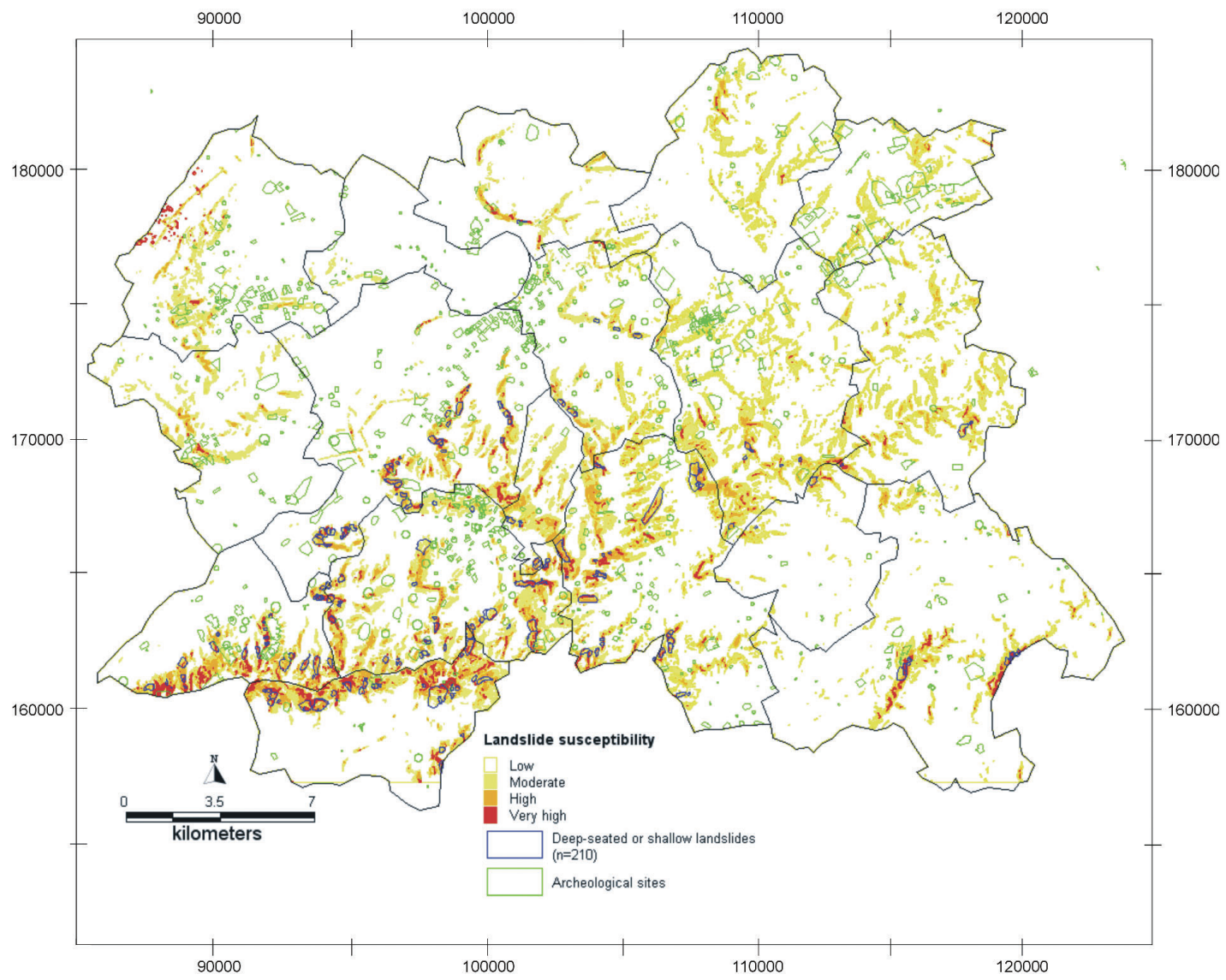

Figure 5 Overlay of the classified landslide susceptibility map of the Flemish Ardennes with the mapped landslides and the archaeological observations extracted from the Central Archaeological Inventory (CAI 2008)

haut et al. (2006; i.e. Area under Receiver Operating Characteristic Curve; Kappa value and other parameters calculated from confusion matrices). From this evaluation procedure, we found that the best landslide susceptibility model can be written as:

$$
\begin{aligned}
\log \left(\frac{\hat{p}}{1-\hat{p}}\right)= & -13.418+(0.386 \times \text { slope gradient }) \\
& +(2.520 \times \mathrm{NW})+(2.948 \times \mathrm{W}) \\
& +(2.043 \times \mathrm{SW})+(2.399 \times \mathrm{S})+(1.653 \times \mathrm{SE}) \\
& +(2.337 \times \mathrm{GeVI})+(2.407 \times \mathrm{GeMe}) \\
& +(1.488 \times \mathrm{Tt})+(1.381 \times \text { KoAa })
\end{aligned}
$$

where $\hat{p}$ is a value between 0 and 1 reflecting the probability of occurrence of a landslide depletion (initiation) area. Slope gradient, the presence of northwest $(N W)$, west $(W)$, southwest (SW), south (S) and southeast (SE) oriented hillslope sections, the presence of the
Vlierzele Member of the Gent Formation (GeVI), the Merelbeke Member of the Gent Formation (GeMe), the Tielt Formation ( $\mathrm{Tt}$ ) and the Aalbeke Member of the Kortrijk Formation (KoAa) are the independent variables influencing landslide occurrence. Slope gradient is the most important environmental factor controlling landslide occurrence, and landslides are expected to occur on hillslopes with a slope gradient above $0.10 \mathrm{~m} \mathrm{~m}^{-1}$ and a southeast to northwest orientation where a lithology rich in swelling clay is located at relatively shallow depth. Landslide accumulation zones are difficult to delineate by this model as the landslide debris is sometimes deposited on slope sections with a $0.05 \mathrm{~m} \mathrm{~m}^{-1}$ slope gradient.

Figure 5 shows the classified landslide susceptibility map produced from model (1). Table 1 provides information on the class boundaries used. It shows that 84 per cent of the mapped landslide grid cells are cor- 
Table 1 Probability values obtained with logistic regression used to classify landslide susceptibility within the $710 \mathrm{~km}^{2}$ study area in the Flemish Ardennes (see Figure 5) and distribution of mapped deep-seated landslides in the four susceptibility classes

\begin{tabular}{|c|c|c|c|c|c|c|c|}
\hline \multirow{2}{*}{$\begin{array}{l}\text { Probability } \\
\text { interval }\end{array}$} & \multirow{2}{*}{$\begin{array}{l}\text { Susceptibility } \\
\text { to landslides }\end{array}$} & \multicolumn{2}{|c|}{$\begin{array}{l}\text { \% Study area } \\
\left(710 \mathrm{~km}^{2}\right)\end{array}$} & \multicolumn{2}{|c|}{$\begin{array}{l}\% \text { Depletion area } \\
\text { of landslide* }\end{array}$} & \multicolumn{2}{|c|}{$\begin{array}{l}\% \text { Total } \\
\text { landslide }\end{array}$} \\
\hline & & & Cumulative & & Cumulative & & Cumulative \\
\hline $0.02-1$ & Very high & 1.5 & 1.5 & 73.8 & 73.8 & 29.8 & 29.8 \\
\hline $0.004-0.02$ & High & 3.0 & 4.5 & 15.9 & 89.7 & 29.0 & 58.8 \\
\hline $0.001-0.004$ & Moderate & 7.0 & 11.5 & 7.6 & 97.3 & 25.2 & 84.0 \\
\hline $0-0.001$ & Low & 88.5 & 100.0 & 2.7 & 100.0 & 16.0 & 100.0 \\
\hline
\end{tabular}

* Location where landslide is initiated and where slope material has been removed and is transported to downslope accumulation area

rectly classified with very high, high or moderate landslide susceptibility, whereas only 7 per cent of the study area (i.e. ca. 7 times the area mapped as affected by landslides) is classified as susceptible to landslides. This high correspondence between the mapped deepseated landslides and the zones with very high, high and moderate landslide susceptibility proves that the susceptibility map is capable of delineating inherent unstable hillslope sections, where landslides can be expected to occur in the future. Validation of this landslide susceptibility map, produced using only data from landslide depletion areas of deep-seated landslides, with the location of mapped shallow landslides further showed that the map is also capable of predicting locations of future shallow landslides because 82.5 per cent of the mapped shallow landslides were correctly classified with very high to moderate susceptibility.

\section{Causal factors for triggering landslides}

Understanding the timing of slope failure and the type of individual factors triggering landslide initiation or reactivation is important to predict when and under which conditions landslides can occur in the future (Varnes and IAEG 1984; Guzzetti et al. 1999; Guzzetti and Tonelli 2004; Calcaterra et al. 2003). However, data on the timing of the deep-seated landslides is limited in the Flemish Ardennes. Deep-seated landslides were considered older than 100 years (Van Den Eeckhaut et al. 2007b). This minimum age of 100 years is based on the absence of historical records reporting the initiation of these slope failures and on the freshness of their morphology. Accelerator mass spectrometry (AMS) radiocarbon dating of one representative landslide suggests that the initiation or the reactivation of the deep-seated landslides occurred in the late Pleistocene or early Holocene (Van Den Eeckhaut et al. $2007 \mathrm{~b})$. Thus, initiation under periglacial conditions cannot be excluded. However, also earthquakes could have triggered the landslides. Ongoing seismicity in the region (Camelbeeck 1993), coincidence of the landslide distribution with active faults (De Vos et al. 1993) and geotechnical slope stability analysis showing that inducing slope failure without earthquake shaking is unlikely (Keersmaekers et al. 2005) are indicators (Jibson 1996) supporting a seismic origin for the deep-seated landslides in the Flemish Ardennes (Ost et al. 2003).

For recent landslides a historical catalogue of landslide events was compiled from interviews with people living close to the affected area and people working in technical services in the investigated municipalities, and from a detailed analysis of old newspapers and technical and scientific reports. In total, information on the month and year of occurrence was obtained for 63 events. Forty-nine events were reactivations inside old landslides (i.e. several of these events can have occurred inside one old landslide) and 14 were firsttime initiations. The oldest reported event in the landslide catalogue occurred in February 1828 (close to city centre of Oudenaarde). However, with only 3 of 63 reported events occurring before 1966, and a maximum of reported events in the period from 1992 to 2007, the regional inventory is considered incomplete for shallow landslides occurring before 1992. Recent landslide events mainly occurred in winter and spring (Figure 6) with maxima in January ( $\mathrm{n}=17$; $27.0 \%)$, February $(\mathrm{n}=21 ; 33.3 \%)$ and March $(\mathrm{n}=7$; $11.1 \%$ ), after several months for which more than $100 \mathrm{~mm}$ rainfall per month was recorded, in combi- 


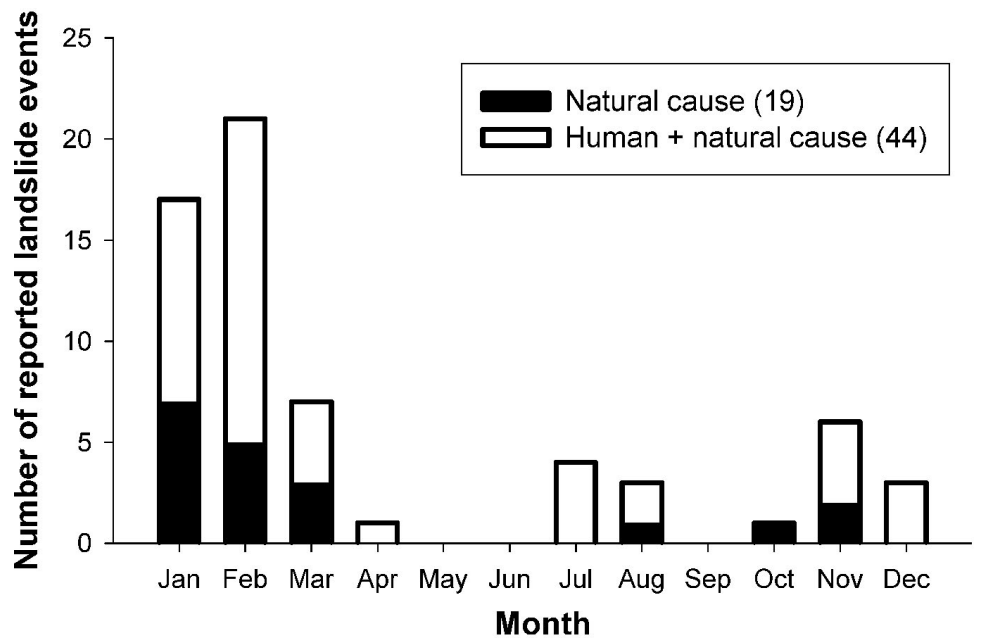

Figure 6 Number of reported landslide events (1904-2007) for which data on month and year of the slope failure is available. Landslide events include first time initiations and reactivations of older landslides. Landslides that were reactivated several times (e.g. Figure 4C,D) are included more than once in the graph. 'Human + natural cause': the reported landslide event occurred shortly after human actions reducing slope stability had taken place on or close to the affected site. 'Natural cause': no human actions had taken place on or close to the affected site prior the reported landslide event

nation with an annual rainfall total above $1000 \mathrm{~mm}$. The influence of human activities on recent slope failures is discussed in one of the following sections.

\section{How does landslide susceptibility affect human activities?}

Influence of landslides on land use

Information about the land use on landslide-affected sites was compiled during the field visit and, if necessary, additional information was obtained from 2002 orthophotos. Especially on deep-seated landslides the actual land use is determined by the presence of the slope failure. Agricultural activities are hampered by the hummocky soil surface and by the wet soil conditions resulting from the ponding of water exfiltrating at the base of the main scarp. Currently most of the 163 deep-seated landslides are completely (i.e. $49.7 \%$ ) or partly (i.e. $27.0 \%$ ) located under forest. For partly forested landslides often only the main scarp and the remaining part of the depletion area are forested, whereas the accumulation zone is used for pasture. Nineteen per cent of the deep-seated landslides are located under pasture. These landslides generally comprise several pastures, and buildings and roads can be located near the pastures. The remaining 4.3 per cent of the landslides is located in gardens and orchards.
The land use on shallow and relatively recent landslides $(n=47)$ corresponds to the land use present at the timing of slope failure. Shallow landslides are mainly (i.e. $61.4 \%$ ) initiated in pastures and only 15.7 per cent and 8.6 per cent of the landslides are completely or partly forested. The remaining 14.3 per cent of the landslides affected gardens, roads and houses. The number of buildings with cracks or other damage caused by landslides is estimated to be at least 350 in the study area.

\section{Influence of landslides on settlements and evolution through time}

Palaeolithicum-AD 1800 Throughout the world landslide risk increases with human occupancy in environmentally vulnerable areas (for example, Michael-Leiba et al. 2003; Meusburger and Alewell 2008). For the Flemish Ardennes, this was never investigated. Although results of the previous section show that currently deep-seated landslides are mainly located under forest or pasture, it is believed that over time human occupancy on landslide-susceptible sites is indeed increasing. Two different studies were carried out to test whether in the past people living in the Flemish Ardennes better understood the environment with the presence of old landslides and inherently unstable hillslopes, hence avoiding such sites for con- 
struction. If this hypothesis is met then archaeological findings should be mainly located on sites with low landslide susceptibility (i.e. first study: Palaeolithicum-AD 1800). In contrast with the past situation where people were familiar with the local environment, currently landowners and land use planners are suggested to pay less attention to local slope stability when carrying out construction works (i.e. second study: AD 1770-AD 2002).

In the first study the landslide inventory and landslide susceptibility map were confronted with the location of archaeological sites in the study area. This approach is similar to the one used by Lollino and Audisio (2006) to ascertain the risk of landsliding to cultural heritage included in the UNESCO World Heritage List in Italy. For our study in the Flemish Ardennes, the archaeological data are taken from the Central Archaeological Inventory (Meylemans 2004; Van Daele et al. 2004; CAI 2008), an electronic relational database consisting of a vector map indicating the location of the archaeological sites and of Access tables containing information on the location, archaeological structure, age, interpretation and source. The Central Archaeological Inventory is designed for heritage management and includes more than 22000 archaeological locations (Palaeolithicum-AD 1800) for the whole of Flanders. Given that archaeological settings from various sources are included, this database contains information with different accuracy (Van Daele et al. 2004). However, the database is currently the best available archaeological inventory for the study area.

The comparison of the landslide inventory and landslide susceptibility map with all archaeological observations in the Flemish Ardennes (Figure 5) confirms that there is a very limited presence of prehistoric settlements or stray finds on landslide-affected or landslide-susceptible hillslopes. This favours our hypothesis, i.e. that people in prehistoric and historic times were more familiar with natural hazards such as landslides and therefore avoided these landslidesusceptible areas. Due to the limited presence of archaeological findings, a more elaborated comparison of the landslide inventory and landslide susceptibility maps with archaeological data from detailed historical periods was not useful. Care should be taken when drawing final conclusions because the absence of historical settlements on unstable hillslopes might reflect that archaeological findings have been removed or covered with debris after landsliding or water erosion, or that so far archaeological studies have focused on the cropped loess plateaus and not on the landslide-susceptible hillslopes that are often located under forest. This last comment is confirmed by local archaeologists and is illustrated in Figure 7, where locations of archaeological findings and mapped landslides are overlain on an excerpt of the topographical map of 2002. Although it is not known whether a survey was carried out on the hillslopes affected by landslides, Figure 7 indicates several archaeological findings on the plateaus, but only one on hillslopes. Furthermore it is also important to note that this study only focuses on the influence of slope stability on the location of archaeological settlements. We acknowledge that the spatial pattern of the settlements is determined by many other strategic, political and socioeconomic factors, but a more elaborate study is currently not possible due to the lack of detailed information on the criteria for selecting settlement sites during different archaeological periods. In this context it is, however, important to note that although the factors influencing the location of settlements are believed to change over time, (pre)historic people seem to have always avoided instable zones.

$A D$ 1770-AD 2002 Given that the Central Archaeological Inventory focuses on observations older than AD 1800, the second study addresses the more recent human activity on landslide-affected hillslopes. More specifically, for the municipalities of Ronse and Maarkedal (Figure 2), the landslide inventory was confronted with historical maps to study the development of buildings inside mapped landslides. For Ronse and Maarkedal, the regional landslide inventory shows 59 landslides. Buildings located inside mapped landslides were digitised in a GIS from georeferenced scans of:

1 the Ferraris map (i.e. Carte-de-Cabinet of the Austrian Netherlands 1771-1778; 1:18 500)

2 the Popp map, a cadastral atlas of the Belgian municipalities (i.e. Atlas cadastral parcellaire de la Belgique publié avec I'autorisation du Gouvernement sous les auspices de Monsieur le Ministre des Finances ca. 1860: 1:1250, 1:2500 or 1:5000)

3 the topographical maps of 1951-1959 (sheet 30/1-2 of 1951, sheet 30/5-6 of 1951, sheet 29/3-4 of 1959 and sheet 29/7-8 of 1958; NGI; 1:15 000)

4 the digital topographical map of 2002 (NGl; $1: 10000)$.

Two possible errors influence the accuracy of the number of digitised houses within mapped landslides. First, there are map errors either related to the planimetric accuracy of the original historical maps (for 

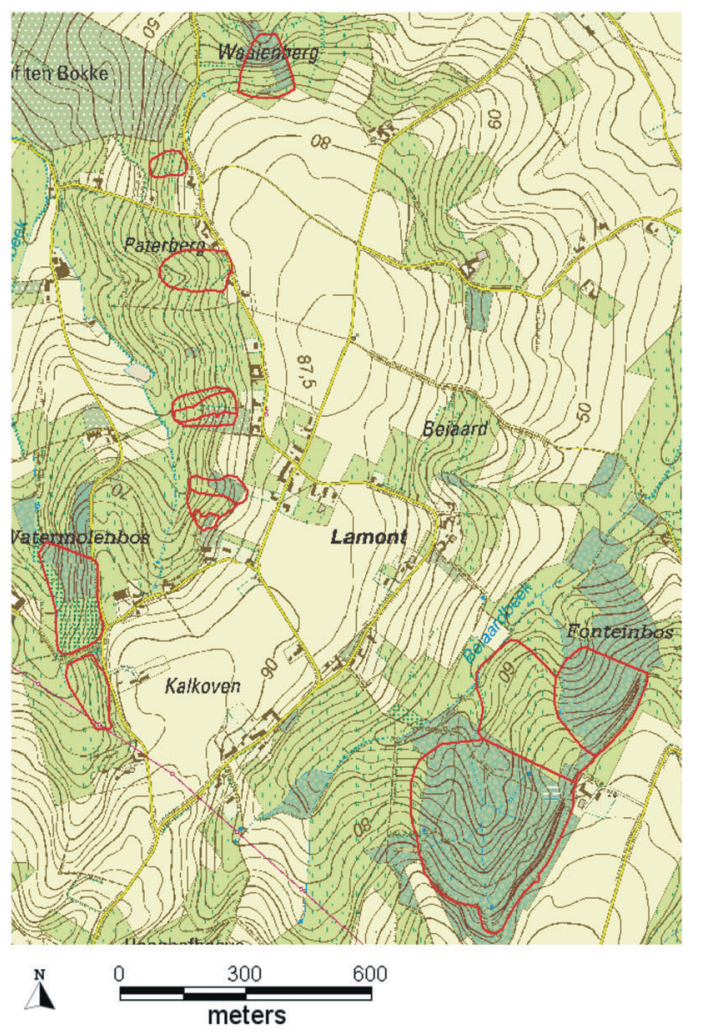

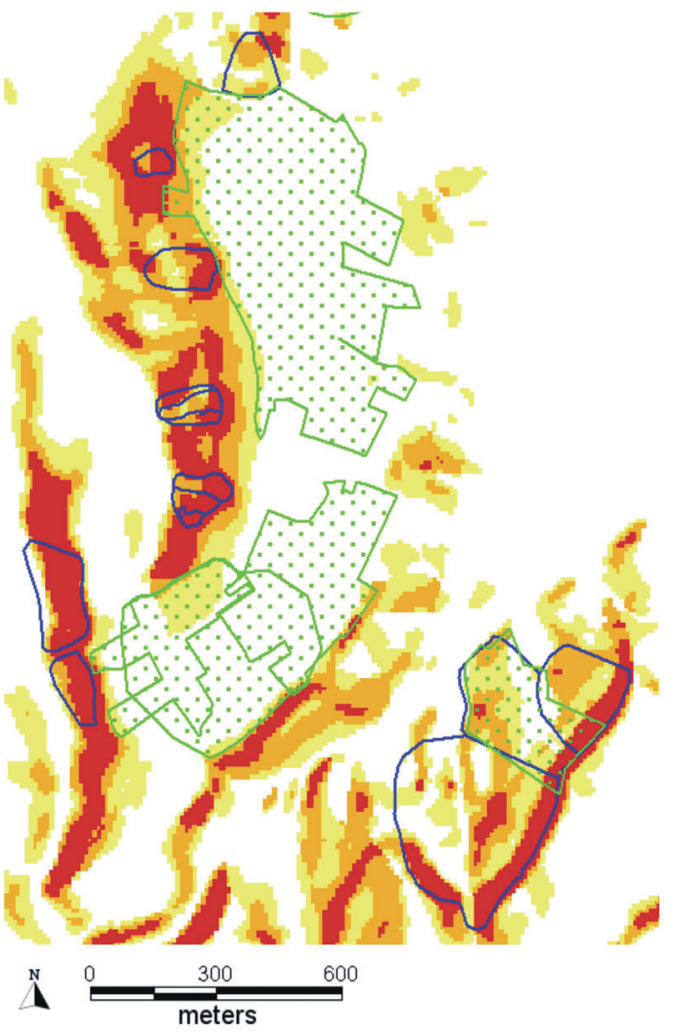

Landslide susceptibility

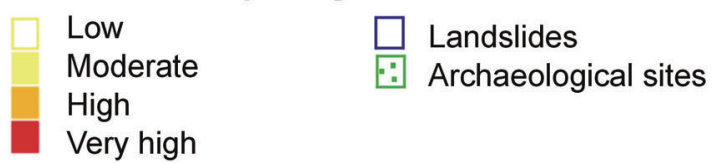

Figure 7 Detail of Paterberg and Waaienberg hills (Kluisbergen; see Figure 2 for location in the study area). (A) Excerpt of topographical map (NGI 2002) with indication of landslides. (B) Excerpt of classified landslide susceptibility map with indication of landslides and archaeological sites and stray finds (CAI 2008). Whereas several historical findings were found on croplands located on loess-covered plateaus, the inventory contains almost no archaeological sites on the forested or grassed landslide-affected hillslopes. The pasture southeast of the Beiaardbeek river is one of the few landslide-affected sites where stray finds were found

example, degree of rotation, shrinkage and stretching) or resulting from scanning and georeferencing of the maps (see for example Figure 8). Map errors have only limited influence on the results, because the relative position of the buildings with respect to roads and field boundaries were evaluated during the digitising of buildings inside mapped landslides. This means that even if the overlay of the mapped landslides and the georeferenced historical map showed that a building on the historical map was located inside a mapped landslide, the person analysing the data may have decided to exclude the building because the building is only located inside the landslide because of low planimetric accuracy of the historical map. For the same reason buildings located outside a landslide on a georeferenced historical map could be included in the analysis. Secondly, there are errors dealing with the digitising of the buildings, more specifically with the fact that some nearly contiguous buildings (for example, farms and stables) are mapped as one building on one of the historical maps and as several separate buildings on another historical map. By 
Buildings on Ferraris map (1771-1778; $\mathbf{n = 2 3 )}$

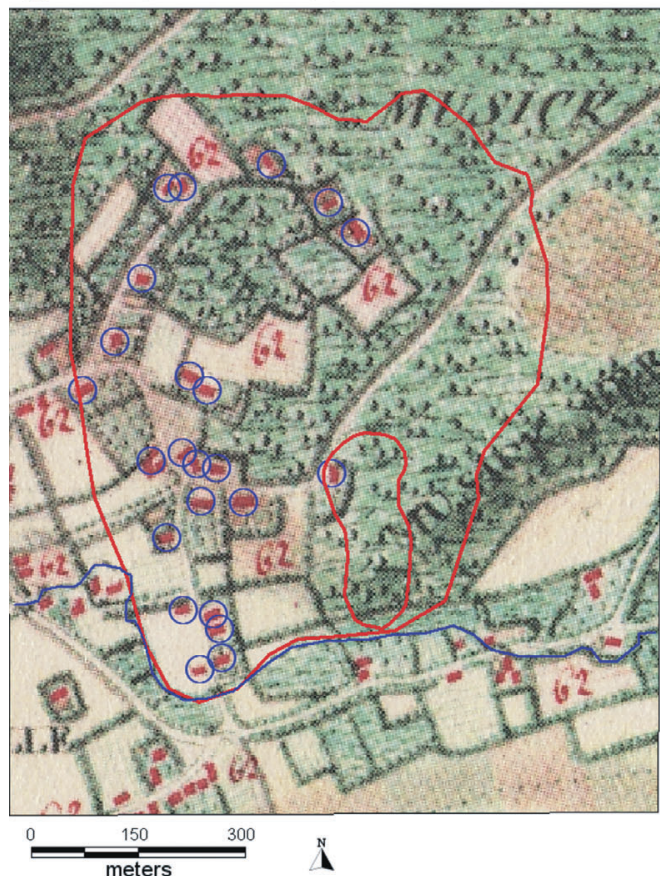

Buildings on topographical map (1951; n=29)

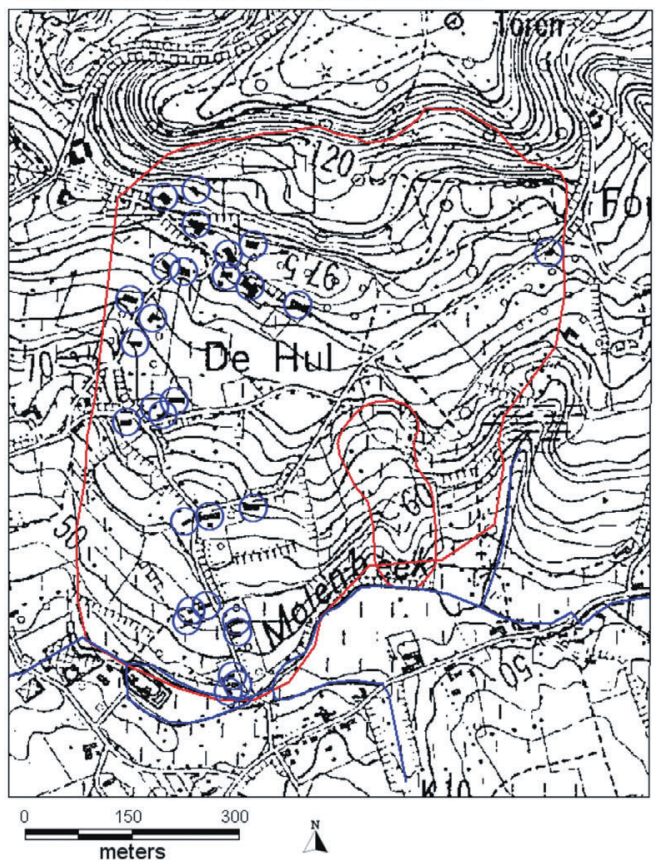

Buildings on Popp map (1860; $\mathbf{n = 2 5 )}$

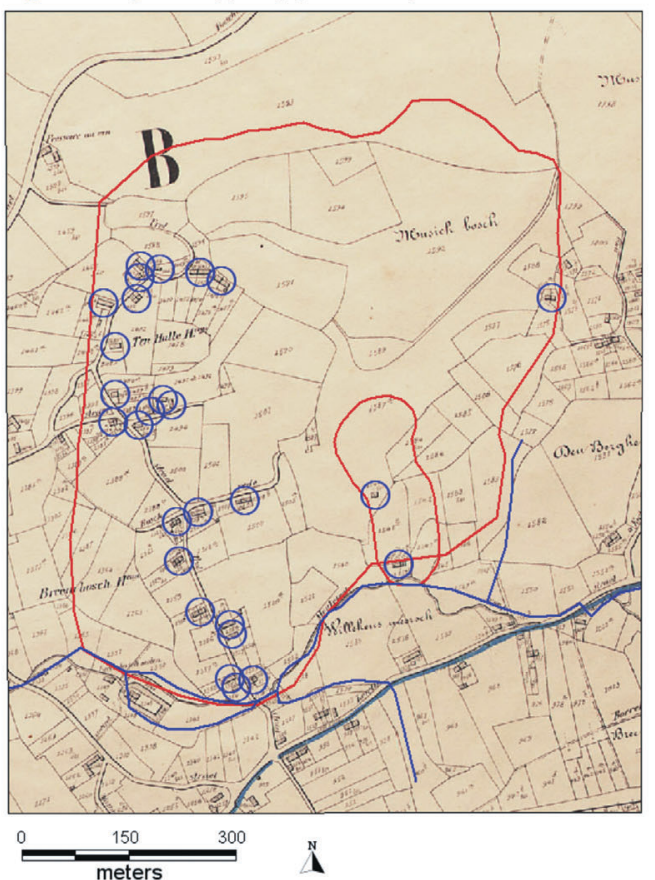

Buildings on topographical map (2002; $n=65)$

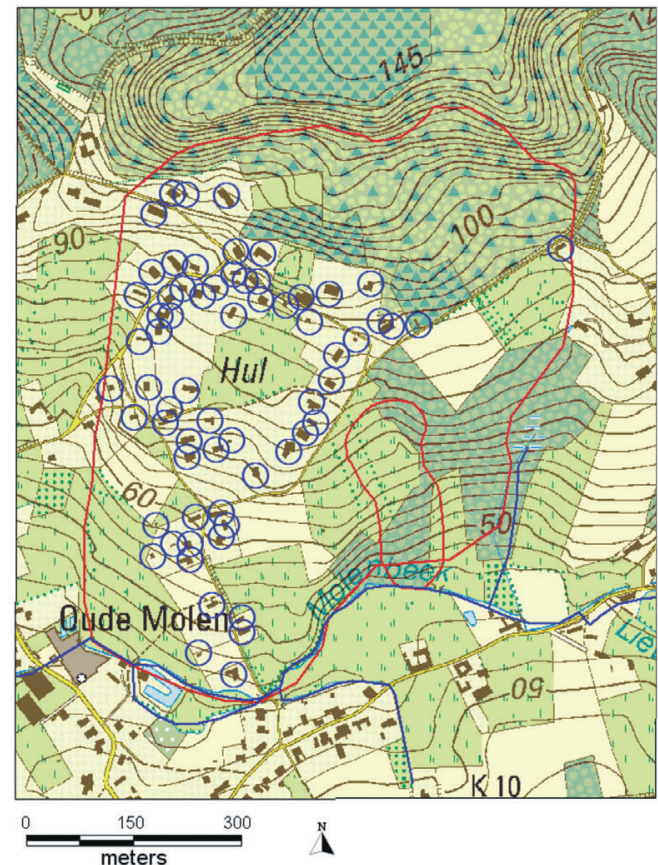

Figure 8 Development of the number of buildings within the Muziekberg landslide (Ronse; see Figure 2 for location in the study area) during the period 1777-2002 
accounting for these buildings as consistently as possible on the four historical maps, this second type of error was limited.

Figure 8 shows the development of buildings observed on the Muziekberg landslide (Ronse; Figure 2). With an affected area of $42 \mathrm{ha}$, this is the largest landslide of the Flemish Ardennes. Although, (a) morphological characteristics typical of landslides (i.e. main scarp, reverse slope, landslide foot), (b) a more recent landslide of 1926 and (c) the displacement of the river downslope of the landslide foot by landslide debris are clearly visible on LIDAR-derived hillshade and contour line maps (Figure 3), many landowners constructed their house on this site. Whereas the Ferraris map, the Popp map and the topographical map of 1958 show the location of 23, 25 and 29 buildings, the topographical map of 2002 shows the location of 65 buildings within this landslide. The increase in number of buildings was not that large in all other large landslides. The development of a residential area on the Muziekberg landslide can be explained by the vicinity of the city of Ronse, the nice view of the Rone valley and the large size of the landslide, making it more difficult to identify. Interviews with people living within this landslide confirm that most landowners became aware of the fact that their house was located within a landslide only after the first landslide-induced damage occurred.

Figure 9 summarises the results obtained for all landslides located within the two studied municipalities. Figure 9A shows that the number of landslides in which buildings were constructed only increased from 14 (or $22.0 \%$ ) out of 59 mapped landslides around 1777 to 16 (or $27.1 \%$ ) out of 59 mapped landslides around 2002. However, the total number of houses located within an old landslide increased from 109 buildings around 1777 to 207 around 2002. With 150 buildings around 1955 and 207 buildings around 2002, new buildings on landslide-affected sites were mainly constructed during the last five decades investigated in the analysis. This increasing trend in the number of houses within all landslides (Figure 9B) is similar to the development observed on the Muziekberg landslide (Figure 8). We acknowledge that many other factors influence a person's decision to live on landslide-affected hillslopes, and that a detailed multidisciplinary study is required to unravel the decision strategy. From our knowledge of the region, however, a lack of construction sites in areas without landslide risk or significant price differences between building grounds on landslide-free and landslide-affected sites can be excluded as important factors determining the observed increase of new buildings within landslides.

\section{How do humans affect landslides?}

\author{
Human actions reported to have contributed to \\ landslide activity
}

For the recent landslide events information on natural and anthropogenic causal factors were stored in the historical landslide catalogue. Figure 6 shows that 44 $(70 \%)$ of the 63 reported events occurred shortly after human actions reducing slope stability had taken place on or close to the affected site. Figure 10 provides more detailed information on the type of human actions that decreased local slope stability. Note that in contrast to Figure 6 where the number of landslide events is shown (i.e. one landslide can have several reported landslide events), Figure 10 shows the number of active landslides. Information on all mapped active landslides, if available, is included and not only information on landslides for which detailed information on the timing of occurrence was obtained. For many of the 43 landslides ( $20 \%$ of 210 ) that were observed or reported to be active, both natural and anthropogenic factors contribute to the local instability. Both types of factors have more or less the same frequency (Figure 10). As mentioned before, natural triggering factors of recent landslides are always high antecedent rainfall depths. Important human actions decreasing slope stability are overloading of the depletion area, for example, through construction of buildings and other infrastructure, removal of hillslope material (i.e. lateral support) for construction works, poor drainage due to insufficient sewerage systems, obstruction of springs and increased surface runoff from the upslope drainage area towards the main scarp.

Most natural and anthropogenic factors reported to have caused slope failure have influenced the stability of the Hekkebrugstraat landslide, the most active landslide of the last 20 years (Oudenaarde; Figures 2, 11), for which landslide activity and human actions over the last 50 years have been recorded through observation by local residents and newspaper articles. Additional information on land use changes was obtained from historical maps and aerial photographs (Van Den Eeckhaut et al. 2007c). The Hekkebrugstraat landslide is a rotational earth slide, which is larger in area than the average deep-seated landslide in the Flemish Ardennes. The affected area is $7.1 \mathrm{ha}$, and the total volume of debris displaced by the landslide is estimated between $4.6 \times 10^{5}$ and $6.9 \times 10^{5} \mathrm{~m}^{3}$. Small reactivations of the landslide were reported in the winter or spring of 1960, 1966 and 1988. However, in February 1995 a $140 \times 15 \mathrm{~m}$ slice of hillslope material 
(A)

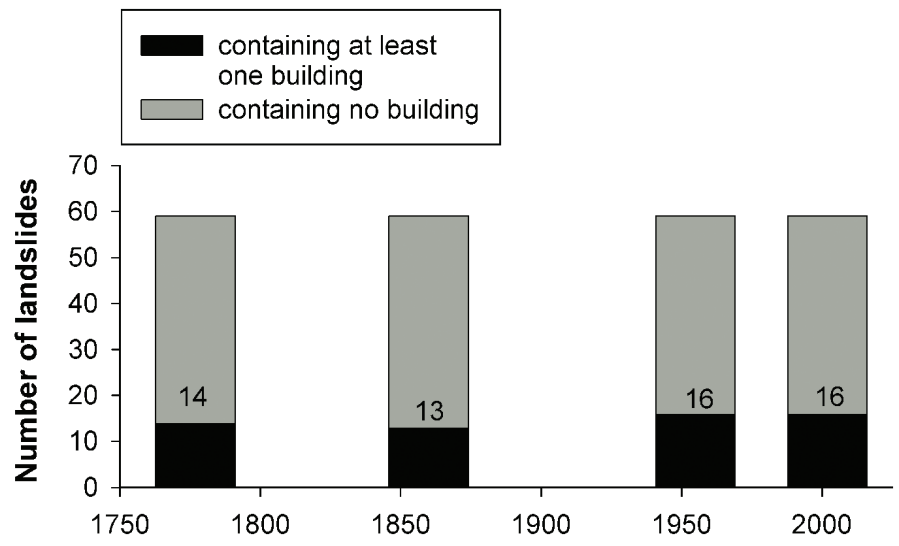

(B)

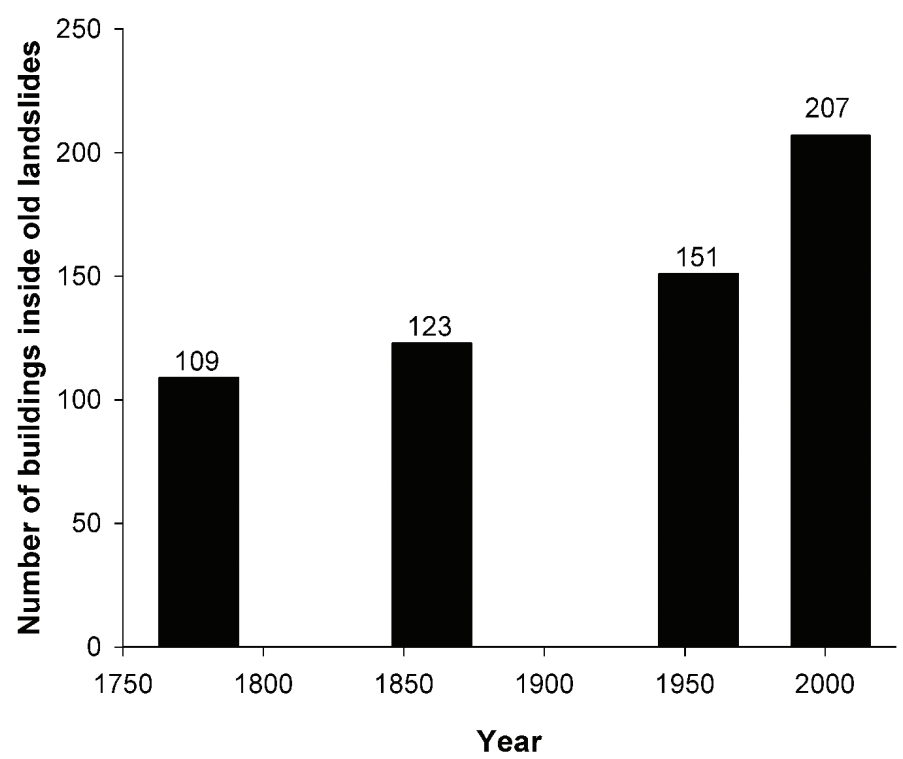

Figure 9 (A) Development of old landslides containing at least one building in Ronse and Maarkedal. The total number of old landslides is 59. (B) Development of buildings within old landslides in Ronse and Maarkedal. Buildings are mapped from the Ferraris map (1771-1778), the Popp map (ca. 1860) and the topographical maps of ca. 1950 (1951-1959) and 2002

fell off the 8-m high main scarp, and reactivated the entire accumulation area. After this reactivation, landslide movement was observed for more than five years and caused damage to houses, roads and other infrastructure. All four landslide events were triggered after monthly rainfall depths above $100 \mathrm{~mm}$ during the previous months. Long periods of high rainfall, and the presence of relatively steep slopes (i.e. $0.14 \mathrm{~m} \mathrm{~m}^{-1}$ ), impermeable clays of the Aalbeke Member and springs at the base of the main scarp (Figure 11) are important natural controlling factors (Table 2). Important anthro- pogenic (Table 2 and Figure 11) actions that decreased the shear strength of the hillslope material were mainly the result of poor water management causing large volumes of Hortonian runoff flowing from the cropland above to the landslide depletion area, the digging of ponds within the landslide area, and poor maintenance of drainage ditches. Shear stress on the surface of rupture was increased by overloading with road fill and soil material, and by removal of lateral support at the toe of the landslide (Table 2). After mitigation measures, i.e. the digging of two 2-m deep drainage 


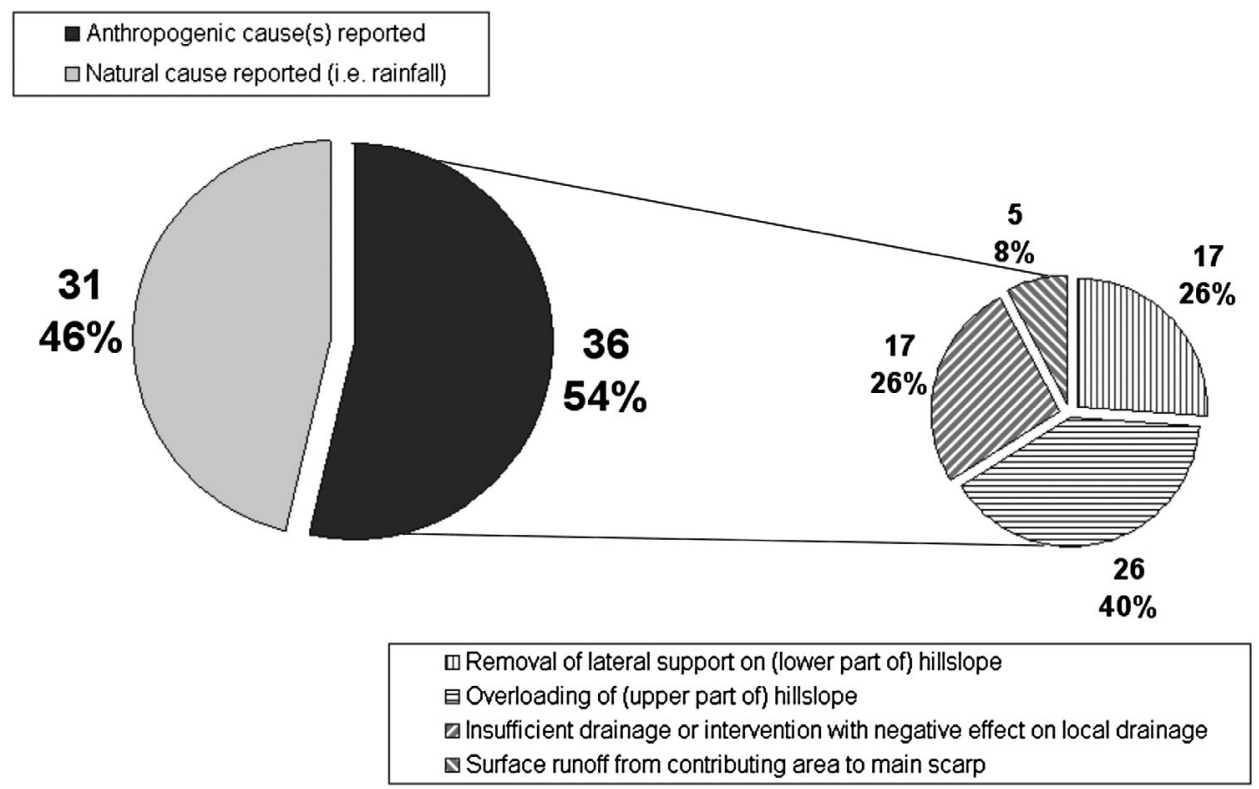

Figure 10 Triggering causal factors of active landslides reported or observed in the Flemish Ardennes. In contrast to Figure 6 where individual events within landslides are given, each active landslide is counted only once here. In total 43 out of $\mathbf{2 1 0}$ landslides were classified as active landslides

trenches through the affected area from the springs at the base of the main scarp to the Marke brook in 2000, the movements in the accumulation area have stopped. Even in the wet year of 2001 (the wettest year since rain recordings started in 1833) the landslide debris was not remobilised. This indicates that the Hekkebrugstraat landslide can be kept in a more or less stable state provided the intensive drainage of the depletion and accumulation area is maintained, and human actions contributing to slope instability are avoided.

\section{What are the implications of landsliding for land management planning?}

Towards a landslide test for prevention and remediation of landslides?

In the Flemish Ardennes 'science meets policy', as the scientific results are used by qualified authorities to inform local people. On the website of the Environment, Nature and Energy Department of the Flemish Government (http://www.Ine.be/themas/bodem/gron dverschuivingen) the landslide inventory and landslide susceptibility maps are available and prevention and mitigation measures are presented.
With regard to landslide prevention, on sites highly susceptible to landslides where at present no human actions have taken place, the strategy of 'avoidance' is highly recommended for the Flemish Ardennes. The construction of new buildings and the installation of other infrastructure (roads, ponds, etc.) should be forbidden in zones with a very high susceptibility to landsliding and on sites already affected by an old landslide. Here, the landslide susceptibility map (Figure 5) plays an important role. As this map was produced in the framework of a project commissioned by the Flemish government (Van Den Eeckhaut et al. 2005b 2007d; http://www.Ine.be/themas/bodem/ grondverschuivingen/grondverschuivingen), qualified authorities can use the map for linking specific landuse regulations to the susceptibility zones and delineating zones where human actions reducing slope stability should be limited. In Belgium, the Flemish Government has introduced a 'water test' in order to avoid both future human activities in areas with a high flood risk, as well as future activities that affect water quality or groundwater level (Mina 2006). Similar to this water test, we propose the establishment of a 'landslide test'. The 'landslide test' would mean that for every decision related to land use changes the com- 
(A) 1952

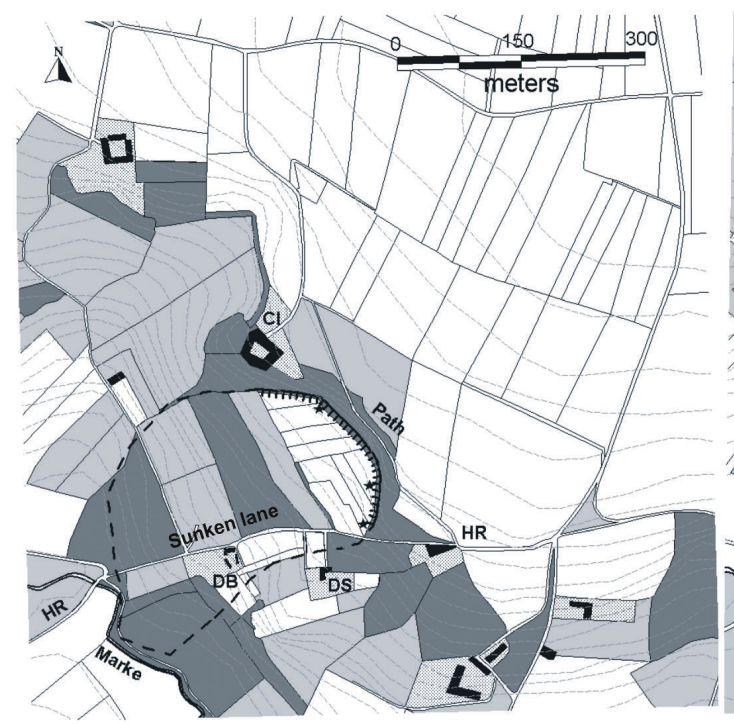

(B) 1996

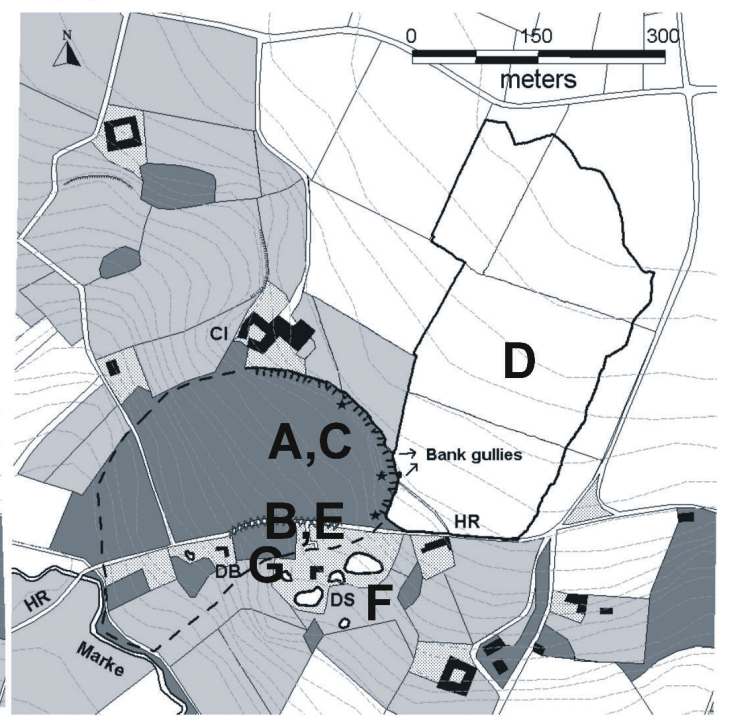

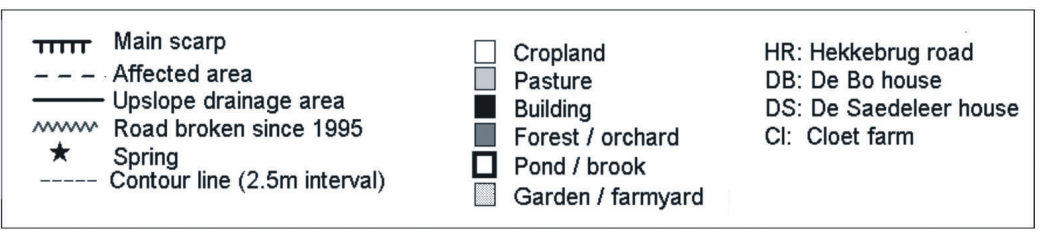

A) 1955: End of agricultural activities and maintenance of drainage ditches in depletion area ;

B) 1947, 1960, 1982, 1988, 1994 and several times after the reactivation of 1995: Road works, filling up and asphalting of sunken lane (the Hekkebrug road loses its drainage function);

C) From 1955 to 2000: Decreased drainage due to poor maintenance of drainage ditches in depletion and accumulation area (only after two $2 \mathrm{~m}$ deep trenches were dug in the affected area from the springs to the Marke brook in 2000, the area was effectively drained);

D) From 1980s: Increased surface runoff from upslope cropland to main scarp due to the increase of plot size and the growing of maize;

E) 1980: Installation of closed drainage pipes along the Hekkebrug road in the affected area (increased evacuation of surface runoff from upslope cropland to Marke brook, decreased evacuation of water in the affected area);

F) 1993: Creation of three large ponds and deposition of 50 truck loads soil material to establish a garden;

G) 2000 and 2001: Removal of toeslope upslope from the DB house and relocation of debris back upslope in the depletion area.

Figure 11 Land use changes decreasing local slope stability (A-G) in the vicinity of the Hekkebrugstraat landslide (Oudenaarde; see Figure 2 for location in the study area). (A) Situation around 1952 based on aerial photograph interpretation. (B) Situation around 1996 based on aerial photograph interpretation and field observations

petent authorities are obliged to evaluate the impact on the 'landslide system'. The 'landslide system' consists of the marginally stable hillslope on which, or close to which the human action is planned. This marginally stable hillslope is characterised by a given lithology, topography and hydrology, and can be located outside or inside an existing landslide. The landslide system also includes past human actions around the area where the new action is planned. This is very important as it concerns the impact of a planned action on neighbouring buildings or infrastructure. New buildings and infrastructure within a marginally stable area can indeed be stable and safe if adequate structural measures are implemented during their construction and if these implementations are maintained afterwards. However, the impact of the new construction works on nearby buildings and infrastructure, and their influence on the long-term slope stability are often not fully understood. 
Table 2 Factors contributing to the instability of the Hekkebrugstraat landslide by increasing the shear stress or lowering the shear strength. Although established for the Hekkebrugstraat landslide, this compilation of factors is valid for all landslides in the Flemish Ardennes. Characters between brackets refer to land use changes indicated in Figure 11

\begin{tabular}{|c|c|c|}
\hline Factors contributing to & Type & \\
\hline \multirow{8}{*}{$\begin{array}{l}\text { High shear } \\
\text { stress (external) }\end{array}$} & Overloading & Road fill (B) \\
\hline & & Weight of water $(C, F)$ \\
\hline & & Weight of additional soil (F, G) \\
\hline & Removal of lateral support & Removal of toeslopes by human activity (G) \\
\hline & & Creation of ponds $(F)$ \\
\hline & & Windthrow of trees on main scarp \\
\hline & Lateral pressure & Water in ponds $(\mathrm{F})$ \\
\hline & & Water in cracks \\
\hline \multirow[t]{5}{*}{$\begin{array}{l}\text { Low shear } \\
\text { strength (internal) }\end{array}$} & $\begin{array}{l}\text { Composition and texture of } \\
\text { lithology }\end{array}$ & $\begin{array}{l}\text { Weak clayey material of Aalbeke Member Kortrijk Formation } \\
\text { rich in smectite, and with low permeability } \\
\text { Successive sub horizontal layers with different infiltration } \\
\text { rates (i.e. surface layers with higher infiltration rate than } \\
\text { underlying clays of Aalbeke Member Kortrijk Formation) }\end{array}$ \\
\hline & $\begin{array}{l}\text { Changes in water regime } \\
\text { (increase in pore water }\end{array}$ & $\begin{array}{l}\text { Long periods of persistent rainfall } \\
\text { Intense rainfall }\end{array}$ \\
\hline & pressure) & Poor maintenance of drainage ditches $(\mathrm{A}, \mathrm{C})$ \\
\hline & & $\begin{array}{l}\text { Land use changes that reduce the effect of the original } \\
\text { drainage }(A, B, D)\end{array}$ \\
\hline & Vegetation & Removal of trees \\
\hline
\end{tabular}

For an important fraction of the landslide-affected sites in the Flemish Ardennes, however, it is too late to choose the strategy of avoidance, because human actions have already taken place on the marginally stable hillslope sections. For these sites it is very important to focus on damage reduction and to implement appropriate remediation measures. Here Table 2 is very important as it shows people living on or close to landslides, local authorities and other land planners which actions should be avoided on landslide-affected and landslide-susceptible sites, and which actions should be implemented to increase shear strength and decrease shear stress. Relatively simple actions such as surface drainage and sometimes modification of the slope geometry are most effective and efficient, especially in the long run (Keersmaekers et al. 2005). We observed that deep-seated landslides, which are located under forest, relatively far from human actions and which have brooklets or drainage ditches evacuating the water exfiltrating from springs at the base of the main scarp, are generally relatively stable (for example, Figure 4A,B), whereas landslides with poor water management and located close to human actions are more susceptible to reactivation (for example, Hekkebrugstraat landslide). Most of the con- ditions observed on the stable landslides can be obtained on populated landslides by implementing the suggested actions.

Taking into account the expected winter rainfall in the next 20-80 years (for example, Van Ypersele and Marbaix 2004; Ntegeka et al. 2008), adequate landslide prevention and mitigation will be necessary to avoid an increase of landslide risk. Landslide events were already reported to occur generally in winter and spring after more than $100 \mathrm{~mm}$ and $1000 \mathrm{~mm}$ rainfall was recorded in the month and year preceding the landslide reactivation or initiation (Van Den Eeckhaut 2006). Given that for many different climate scenarios, general and regional circulation models predict increased winter precipitation for this century (for example, Van Ypersele and Marbaix 2004; Arnell et al. 2005; Christensen and Christensen 2007; Ntegeka et al. 2008), the number of landslide events is expected to increase in the near future if no landslide mitigation measures are implemented.

However, for a last group of landslides, i.e. dormant landslides located in forests, no mitigation but geoconservation measures are required. As the deep-seated landslides in the Flemish Ardennes are relict features, which are irreplaceable if degraded, some typical 
landslides should be protected as geosites. Landslides with the best preserved morphological characteristics such as a clear main scarp and several reverse slopes should be selected for this purpose.

\section{Conclusions}

This study shows that landslide studies in residential areas not only require a detailed analysis of the natural factors reducing slope stability and triggering landslides. Also detailed information on the impact of human activities on and close to inherently unstable hillslopes is needed. In the Flemish Ardennes landsliding is an important degradation process: the regional inventory map contains 210 landslides. We first focused on the natural causes (Figure 1). Application of a logistic regression model showed that hillslope sections oriented towards the south and the northwest, with a slope above $0.10 \mathrm{~m} \mathrm{~m}^{-1}$ and with clay lithology at relatively shallow depth are most susceptible to landsliding. These hillslope sections are classified as very high, high and moderate susceptible on the landslide susceptibility map. Comparison of this susceptibility map with an inventory of archaeological locations and with buildings mapped from historical maps (1777-2002) shows that especially during the last 50 years of the 20th century, the number of houses on landslide-affected hillslopes increased. Investigation of (a) the land use on sites recently affected by slope failures (i.e. mainly pastures often located in the vicinity of houses, but also gardens and roads), (b) causal factors reported to have initiated recent slope failures, and (c) land use changes and causal factors observed at the Hekkebrugstraat landslide reveals that currently humans can significantly reduce slope stability, and initiate or reactivate landslides.

The availability of the landslide susceptibility map allows qualified authorities to link specific land use regulations to the susceptibility zones and to delineate zones where human actions reducing slope stability should be limited. The strategy of avoidance should be followed where possible, and for the prevention of landslides and landslide-related damage a 'landslide test', checking whether a planned action may initiate or reactivate landslides causing damage to the planned or to existing infrastructure, could be developed. Persons living on landslides should take remediation measures, such as the installation of well-maintained drainage systems, to increase slope stability. Otherwise the number of landslide reactivations is expected to increase, as climate models predict higher winter rainfall for this century.
The results obtained in this study are a strong indication for an increasing trend of human influence on landslide-susceptible sites. However, a more elaborate multidisciplinary approach (including for example, physical and historical geographers, archaeologists and anthropologists) taking into account socioeconomical, political, historical, geographical and other factors is needed to unravel a person's decision to build within a landslide susceptible area.

\section{Acknowledgements}

This research is supported by the Research Foundation Flanders. The authors thank Ir. E. Poelman (Provinciaal Centrum voor Milieuonderzoek, Provincie Oost-Vlaanderen), P. Haustraete (Regionaal Landschap Vlaamse Ardennen), Ir. K. Haelterman (Geotechniek, Departement Mobiliteit en Openbare Werken, Vlaamse Overheid), Prof. Dr. J. Maertens (Departement Burgerlijke Bouwkunde, K.U.Leuven), H. De Bo and civil servants from local municipalities.

\section{References}

Arnell N, Tompkins E, Adger N and Delaney K 2005 Vulnerability to abrupt climate change in Europe Technical report 34 Tyndall Centre for Climate Research

Atkinson P M and Massari R 1998 Generalised linear modelling of susceptibility to landsliding in the Central Apennines Computers \& Geosciences 24 373-85

Ayalew L and Yamagishi H 2005 The application of GIS-based logistic regression for landslide susceptibility mapping in the Kakuda-Yahiko Mountains, Central Japan Geomorphology 65 15-31

Begueria S and Lorente A 1999 Landslide hazard mapping by multivariate statistics: comparison of methods and case study in the Spanish Pyrenees The Damocles Project Work Contract EVG1-CT 1999-00007 Technical Report

CAI 2008 Central Archaeological Inventory (http:// cai.erfgoed.net/) Accessed 20 July 2008

Calcaterra D, Parise M and Palma B 2003 Combining historical and geological data for the assessment of the landslide hazard: a case study from Campania, Italy Natural Hazards and Earth System Sciences 3 3-16

Camelbeeck T 1993 Introduction à l'étude des tremblements de terre. La séismicité en Belgique et dans le nord de la France Annales de la Société Géologique du Nord, T.2 (2ème série) 5-22 (in French)

Campling P, Gobin A and Feyen J 2002 Logistic modeling to spatially predict the probability of soil drainage classes Soil Science Society of America Journal 66 1390-401

Carrara A, Cardinali M, Guzzetti F and Reichenbach P 1995 GIS technology in mapping landslide hazard in Carrara A and Guzzetti $\mathbf{F}$ eds Geographical information systems in assessing natural hazards Kluwer Academic, Dordrecht 135-76 
Christensen J H and Christensen O B 2007 A summary of the PRUDENCE model projections of changes in European climate by the end of this century Earth and Environmental Science 81 7-30

Claessens L, Lowe D J, Hayward B W, Schaap B F, Schoorl J M and Veldkamp A 2006 Reconstructing high-magnitude/ low-frequency landslide events based on soil redistribution modelling and a Late-Holocene sediment record from New Zealand Geomorphology 74 29-49

Closson D, Engels P and Demaret X 1999 The use of the soil map of Belgium in the assessment of landslide risk Biotechnology, Agronomy, Society and Environment 3 165-72

Cruden D M 1991 A simple definition of a landslide Bulletin of the International Association of Engineering Geology 43 27-9

Cruden D M and Varnes D J 1996 Landslide types and processes in Turner A K and Schuster R L eds Special Report 247: Landslides, investigation and mitigation Transportation Research Board National Research Council, National Academy Press, Washington DC 36-71

Dai F C, Lee C F and Nhai Y Y 2002 Landslide risk assessment and management: an overview Engineering Geology 64 65-87

Demoulin A, Pissart A and Schroeder C 2003 On the origin of late Quaternary palaeolandslides in the Liège (E Belgium) area International Journal of Earth Sciences 92 795-805

De Vos W, Verniers J, Herbosch A and Vanguestaine M 1993 A new geological map of the Brabant Massif, Belgium Ceological Magazine 130 606-11

Dewitte O, Jasselette J C, Cornet Y, Van Den Eeckhaut M, Collignon A, Poesen J and Demoulin A 2008 Tracking landslide displacement by multi-temporal DTMs: a combined aerial stereophotogrammetric and LIDAR approach in western Belgium Engineering Geology 99 11-22

Glade T and Crozier M J 2005 The nature of landslide hazard impact in Glade T, Anderson $\mathbf{M}$ and Crozier $\mathbf{M} \mathbf{J}$ eds Landslide hazard and risk John Wiley and Sons, Chichester 43-74

Goudie A S 2000 The human impact on the natural environment 5th edn Blackwell, Oxford

Guzzetti F and Tonelli G 2004 Information system on hydrological and geomorphological catastrophes in Italy (SICl): a tool for managing landslide and flood hazards Natural Hazards and Earth System Sciences 4 213-32

Guzzetti F, Carrara A, Cardinali M and Reichenbach P 1999 Landslide hazard evaluation: a review of current techniques and their application in a multi-scale study, Central Italy Geomorphology 31 181-216

Hosmer D W and Lemeshow S 1989 Applied regression analysis Wiley, New York

Hutchinson J N 1967 The free degradation of London clay cliffs Proceedings of the Geotechnical Conference Oslo 1 113-18

IWONL 1987 Text clarifying the Belgian Soil Map, Map sheet 98E Ronse Uitgegeven onder de auspiciën van het Instituut tot aanmoediging van het Wetenschappelijk Onderzoek in Nijverheid en Landbouw, Brussels (in Dutch)
Jacobs P, De Ceukelaire M, De Breuck W and De Moor G 1999a Text clarifying the Belgian Geological Map, Flemish Region, Map sheet 29 Kortrijk 1:50,000 Ministerie van Economische zaken en Ministerie van de Vlaamse Gemeenschap, Brussels (in Dutch)

Jacobs P, Van Lancker V, De Ceukelaire M, De Breuck W and De Moor G 1999b Text clarifying the Belgian Geological Map, Flemish Region, Map sheet 30 Geraardsbergen 1:50,000 Ministerie van Economische zaken en Ministerie van de Vlaamse Gemeenschap, Brussels (in Dutch)

Jibson R W 1996 Use of landslides for paleoseismic analysis Engineering Geology 43 291-323

Keefer D K 1994 The importance of earthquake-induced landslides to long-term slope erosion and slope-failure hazards in seismically active regions Geomorphology $10 \quad 265-$ 84

Keersmaekers R, Maertens J and Van Gemert D 2005 Verkennende studie met betrekking tot massabewegingen in de Vlaamse Ardennen. Deel II: Geotechnisch onderzoek van enkele representatieve sites onderhevig aan massabewegingen Rapport Laboratorium Reyntjens R/30232/04 Rapport in opdracht van de Vlaamse Gemeenschap AMINAL afdeling Land, Brussels (in Dutch)

King G and Zeng L 2001 Logistic regression in rare events data Political Analysis 9 137-63

Lee S 2007 Comparison of landslide susceptibility maps generated through multiple logistic regression for three test areas in Korea Earth Surface Processes and Landforms 32 2133-48

Lollino G and Audisio C 2006 UNESCO World Heritage sites in Italy affected by geological problems, specifically landslide and flood hazard Landslides 3 311-21

Marre A 1987 Le mouvement de terrain du 23/08/86 à Rillyla-Montagne Naissance et évolution Travaux de l'Institut de Géographie de Reims 69-72 95-111 (in French)

Meusburger K and Alewell C 2008 Impacts of anthropogenic and environmental factors on the occurrence of shallow landslides in an alpine catchment (Urseren Valley, Switzerland) Natural Hazards and Earth Systems Sciences 8 509-20

Meylemans E 2004 Drie jaar Centrale Archeologische Inventaris: een overzicht en stand van zaken in SN De opbouw van een archeologisch beleidsinstrument IAP- rapporten 14 Afdeling Monumenten en Landschappen Ministerie van de Vlaamse Gemeenschap, Brussels 9-28 (in Dutch)

Michael-Leiba M, Baynes F, Scott G and Granger K 2003 Regional landslide risk to the Cairns community Natural hazards $30233-49$

Mina 2006 Why a watertest? (http://www.mina.be/uploads/ watertoets_folder.pdf) Accessed 15 September 2008

Ntegeka V, Boukhris O, Willems P, Baguis P and Roulin E 2008 Climate change impact on hydrological extremes along rivers and urban drainage systems in Belgium II. Study of rainfall and ETo climate change scenarios Project for the Belgian Science Policy Office Brussels, Belgium

Ost L, Van Den Eeckhaut M, Poesen J and VanmaerckeGottigny M C 2003 Characteristics and spatial distribution 
of large landslides in the Flemish Ardennes (Belgium) Zeitschrift für Geomorphologie 47 329-50

Panizza M 1999 Relationships between environment and man in terms of landslide induced risk in Casale $\mathbf{R}$ and Margottini Y C eds Floods and landslides Springer, Berlin 1915

Petley D N, Hearn G J, Hart A, Rosser N J, Dunning S A, Oven K and Mitchell W A 2007 Trends in landslide occurrence in Nepal Natural Hazards 43 23-44

Schmidt J and Dikau R 2004 Modeling historical climate variability and slope stability Geomorphology 60 433-47

Soeters R and van Westen C J 1996 Slope stability recognition analysis and zonation in Turner A $\mathbf{K}$ and Schuster $\mathbf{R} \mathbf{L}$ eds Landslides: investigation and mitigation Transportation Research Board Special Report 247 National Academy Press, Washington DC 129-77

Tarantino C, Blonda P and Pasquariello G 2007 Remote sensed data for automatic detection of land-use changes due to human activity in support to landslide studies Natural Hazards 41 245-67

Van Daele K, Meylemans E and De Meyer M 2004 De Centrale Archeologische Inventaris, een databank van archeologische vindplaatsen in SN De opbouw van een archeologisch beleidsinstrument IAP-rapporten 14 Afdeling Monumenten en Landschappen Ministerie van de Vlaamse Gemeenschap, Brussels 29-48 (in Dutch)

Van Den Eeckhaut M 2006 Spatial and temporal patterns of landslides in hilly regions - the Flemish Ardennes (Belgium) $\mathrm{PhD}$ thesis K.U. Leuven, Belgium

Van Den Eeckhaut M, Poesen J, Verstraeten G, Vanacker V, Moeyersons J, Nyssen J and Van Beek L P H 2005a The effectiveness of hillshade maps and expert knowledge in mapping old deep-seated landslides Geomorphology 67 351-63

Van Den Eeckhaut M, Poesen J, Verstraeten G and Govers G 2005b Verkennende studie met betrekking tot massabewegingen in de Vlaamse Ardennen. Deel I: Studiegebied, literatuurstudie, inventarisatie en classificatie (+steekkaarten), statistische en ruimtelijke analyse en methodologie voor het ontwerp van een risicokaart Rapport in Opdracht van de
Vlaamse Gemeenschap AMINAL Afdeling Land, Brussels http://www.Ine.be/themas/bodem/grondverschuivingen/ grondverschuivingen

Van Den Eeckhaut M, Vanwalleghem T, Poesen J, Govers G, Verstraeten G and Vandekerckhove L 2006 Prediction of landslide susceptibility using rare events logistic regression: a case-study in the Flemish Ardennes (Belgium) Geomorphology 76 392-410

Van Den Eeckhaut M, Poesen J, Verstraeten G, Van Acker V, Nyssen J, Moeyersons J, Van Beek L P H and Vandekerckhove $\mathbf{L}$ 2007a The use of LIDAR-derived images for mapping old landslides under forest Earth Surface Processes and Landforms 32 754-69

Van Den Eeckhaut M, Verstraeten G and Poesen J 2007b Morphology and internal structure of a dormant landslide in a hilly area: the Collinabos landslide (Belgium) Geomorphology 89 258-73

Van Den Eeckhaut M, Poesen J, Dewitte O, Demoulin A, De Bo H and Vanmaercke-Gottigny M C 2007c Reactivation of old landslides: lessons learned from a case-study in the Flemish Ardennes (Belgium) Soil Use and Management 23 200-11

Van Den Eeckhaut M, Poesen J and Verstraeten G 2007d Vervolgproject: Opstellen van een gevoeligheidskaart met betrekking tot grondverschuivingen voor de Vlaamse Ardennen Rapport In opdracht van Vlaamse Overheid Departement Leefmilieu Natuur en Energie Afdeling Land en Bodembescherming, Ondergrond, Natuurlijke Rijkdommen, Brussel http://www.Ine.be/themas/bodem/grond verschuivingen/grondverschuivingen (in Dutch)

Vanmaercke-Gottigny M C 1980 Landslides as a morphogenetic phenomenon in a hilly region of Flanders (Belgium) in De Boodt $M$ and Gabriels D eds Assessment of erosion John Wiley and Sons, Chichester 475-84

Van Ypersele J P and Marbaix P 2004 Impact of climatic changes in Belgium Greenpeace, Brussels

Varnes D J and IAEG Commission on Landslides and other Mass-Movements 1984 Landslide hazard zonation: a review of principles and practice UNESCO Press, Paris 